\title{
Constraints Perceived by Farmers in the Use of E-Choupal
}

\author{
Verma AP ${ }^{1 *}$, Ansari MA² and Parameswaranaik ${ }^{1}$ \\ ${ }^{1}$ Dairy Extension Division, ICAR- National Dairy Research Institute, India \\ ${ }^{2}$ Department of Agricultural Communication, College of Agriculture, India
}

Submission: October 10, 2017; Published: November 10, 2017

"Corresponding author: Verma AP, Dairy Extension Division, ICAR- National Dairy Research Institute, Karnal, 132001, India, Email: arjunverma45753@gmail.com

\begin{abstract}
Exchanging of information is critical for different type of stakeholders in agriculture value chain in order to reduce the asymmetries in information and communication as well as to reduce the malicious circle of poverty. In this context, e-Choupal is seen as one of the most important means of achieving such a major transformation. But in other hand there are some constraints in using e-Choupal, so in order to ascertain perceived constraints by the farmers in use of e-Choupal, the study was undertaken in Gonda district of Uttar Pradesh. A sample of total 120 farmers who are the users of e-Choupal was selected through simple random sampling method. The collected data were analysed through Garret ranking method.

Major constraints perceived by the farmers were, lack of awareness about services of e-Choupal with Garrett's Mean Score (GMS) 52.98; accessibility of e-Choupal is not easy (44.73GMS) to information not provided in local language (24.88GMS) were the major constraints. So the study suggests that there is a need to ensure that the problems of the farmers are being met in solving the problem, in order to enable the farming community derive maximum benefits on better access to information services through the use of e-Choupal for different purpose of agriculture and other rural developmental activities.
\end{abstract}

Keywords: E-Choupal; Constraints; Farmers; Garret ranking technique

\section{Introduction}

The desire to promote better information access to improve the socio-economic condition of the farmers has always been the top priority of extension professional and rural advisory service providers [1]. According to FAO [2], exchanging information is critical for different type of stakeholders in agriculture value chain in order to reduce the asymmetries in information and communication as well as to reduce the malicious circle of poverty. Parameswaranaik et al. [3] reported that for every technology there will be some constraints in using by farmers. Yet despite economically vital role, Indian agriculture has until recently been regulated in an archaic fashion that limits its productivity.

Non optimal farming practices and capricious weather pattern left post-independence India with an underperforming agricultural sector, acute food shortages, and dependence on food imports. To tackle these challenges of Indian agriculture, ITC (Indian Tobacco Company) conceived e-Choupal that places computers with internet access in rural farming villages. E-Choupal is internet kiosk, village gathering place and e-Commerce hub all rolled into one. E-Choupal also established a low- cost fulfillment system focused on the needs of rural India, which helps in mitigating rural isolation, create more transparency for farmers, and improve their productivity and income. E-Choupal aims to provide rural people ready access to specific real time information and customized knowledge in their native language. The E-choupal is run by an operator called the "Sanchalak" who himself is a farmer [4]. Thus, the present research was designed to study the constraints of farmers in usage of E-Choupal, the specific objective "To ascertain the perceived constraints of farmers in usage of E-Choupal services in Gonad district of Uttar Pradesh".

\section{Methodology}

The statistical population of the present research study includes farmers who are the users of E-Choupal and involved 
in the agricultural activities. Total, 120 farmers were selected randomly from four selected villages of Gonda district districts of Uttar Pradesh. The problems which farmers could face during usage of E-Choupal were listed following extensive review of literature. The list of statements was translated into local language and the farmers were asked to identify major constraints faced by them in decreasing order of significance. The data were collected through personal interview with the help of pre-tested structured interview schedule. The interview schedule containing a list of constraints and the farmers were asked to rank each factor based on the severity of the factor.

All the listed constraints were ranked by the farmers, and after that method of combining of incomplete order of merit ranking as advocated by Garrett [5] was followed accordingly. The collected data was tabulated and analysed statistically by using Garrett's ranking technique. The obtained values were transformed into scores by using the Garrett's ranking formula as follows;

\section{Results and Discussion}

Table1: Constraints perceived by respondents in usage of e-Choupal $(n=120)$.

\begin{tabular}{|c|c|c|c|c|}
\hline Sl. No & Constraints & Total Score & Garret Score & Ranks \\
\hline 1 & Lack of awareness among the society & 6358 & 52.98 & I \\
\hline 2 & Accessibility is not easy & 5367 & 44.73 & II \\
\hline 3 & Power fluctuations & 4895 & 40.79 & III \\
\hline 4 & Cost involved in getting service & 4627 & 38.56 & IV \\
\hline 5 & Poor Network Connectivity & 3686 & 30.72 & V \\
\hline 6 & Lack of organized information & 3456 & 28.8 & VI \\
\hline 7 & Information not provided in local & 2986 & 24.88 & VII \\
\hline
\end{tabular}

The results revealed from (Table 1), that lack of awareness about the services of E-Choupal among the farmers was the major constraint that prevented the farmers from using its services. The Garret Mean Score for this statement is 52.98 and ranks first among all constraints and this might be due to lack of mass media exposure. The second most important constraint was accessibility of e-Choupal is not easy and with Garrett's scores 44.73 , it may be attributed to the reasons like lack of transportation facility in the study area. And power fluctuation was listed as the third most severe constraint by the farmers when they visit e-Choupal, even power backup supply system did not work due to shortage of power for several hours so this another major constraints perceived by the respondents with Garrett's score 40.79 .

Findings of the study supported by Senthilkumar \& Chander [6] revealed that among the constraints perceived by dairy farmers in accessing Village Information Centre, general problem like power failure, connectivity problem, inadequacy of computer etc. was considered as foremost constraints. Sarvanan [7] \& Olaniyi [8] also reported that infrastructural inadequacy, including power supply, telecom connectivity and inaccessibility in rural areas are the major constraint in utilizing ICT tools.
Percent position $=\frac{100\left(R_{i j}-0.5\right)}{N_{J}}$

Where,

$\mathrm{R}_{\mathrm{ij}}=$ Rank given by $\mathrm{i}^{\text {th }}$ factor and $\mathrm{j}^{\text {th }}$ individual

$\mathrm{N}_{\mathrm{J}}=$ Number of factor ranked by $j^{\text {th }}$ individual

The percent position was calculated for the ranks as well as their corresponding Garrett's table value. The current work has seven constraints and respondents asked to rank each constraint according to severity of constraints faced by them. Collected data was arranged in factor (constraints) and rank wise, later Garrett's value was multiplied with Garrett's table value. Total score was calculated by multiplying the Garrett's value with the rank assigned by the respondents. Further, Garrett's score respondent sand rank was assigned according to Garrett's score. was calculated by dividing the total score by the number of

Another important economic constraint 'Cost involved in getting service' was ranked fourth with a GMS of 38.56. It might be due to the people perception that the cost of using e-Choupal was high. It was comparable with the findings of Singh et al. [9] who revealed that high cost for service provided was second most important constraint.

Findings of the study are in conformity with Ogbonna \& Agwu [10] who revealed that major constraints in utilization of ICT by rural farmers are due to low income earning capacity. 'Poor Network Connectivity' was considered as fifth important constraint as perceived by farmers with Garrett's score 30.72 . The findings of the study are comparable with Singh et al. [9] and Syiem \& Saravanan [1] who reported that poor connectivity of network is one problem faced by the farmers in using mobile phones. Another constraints 'lack of organized and updated information was ranked sixth with Garrett's score 28.80 Information not provided in local language was ranked seventh with Garrett's score 24.88. Findings of the study are in line with Saravanan [7] who reported that availability of relevant and localized content in an appropriate language are common challenges faced by farmers in accessing information through ICTs $[11,12]$. 


\section{Conclusion}

From the above study, it can be concluded that farmers faced some constraints in usages of E-Choupal. Realization of full potential of E-Choupal is constrained by inadequacy in different areas like Lack of awareness about various services of E-Choupal among the farming community; Accessibility is not easy, Power fluctuation, Economic constraint, Poor Network Connectivity. In spite of these few constraints e-Choupal showed promising and better option for the dissemination of information among farmers in different states [13]. There is a need to ensure that the problems of the farmers are being met in solving the problem in order to enable the farming community derive maximum benefits on better access to information services through the use of E-Choupal for different purpose of agriculture and other developmental activities. Further attempt should be made to create awareness among farming community about various services offered by e-Choupal.

\section{References}

1. Syiem R, Saravanan R (2015) Access and Usage of ICTs for Agriculture and Rural Development by the tribal farmers in Meghalaya State of North-East India. Journal of Agricultural Informatics 6 (3): 24-41.

2. FAO (2011) The role of Information and Communication Technologies (ICTs) in the improvement of Agriculture value chains.

3. Parameswaranaik JR, Kumar S, Kumar MCT, Arun KP, Bhawar RS (2015) Perceived Constraints of Dairy Farmers towards Climate Variability in Northern Dry Zone of Karnataka State. Journal of Global Communication 8(2): 171-173.
4. Jain S, Purohit A (2015) Utilization of agriculture service of e-choupal by rural people of Rajasthan. International journal of Home Science Extension and Communication Management 2(1): 45-48.

5. Garrett HE, Woodworth RS (1969) Statistics in Psychology and Education. Vakils, Feffer and Simons Pvt. Ltd., Bombay, India, p. 329.

6. Senthilkumar S, Chander M (2009) Constraints perceived by dairy farmers in accessing ICT-enabled Village Information Centres. Indian J Anim Res 43(4): 282-284.

7. Saravanan R (2010) India profile. In: Saravananed R ICTs for Agricultural Extension: Global Experiments, Innovations and Experiences. New India Publishing Agency, New Delhi, India.

8. Olaniyi OA (2013) Assessment of utilization of Information and Communication Technologies (ICTs) among poultry farmers in Nigeria: An Emerging Challenge. Transnational Journal of Science and Technology 3(7): 361-369.

9. Singh M, Burman RR, Sharma JP, Sangeetha V, Iquebal MA (2015) Constraints Faced in Mobile Based Agro-Advisory Services and Strategy for Enhancing the Effectiveness of mKRISHI. Indian Res J Ext Edu 15 (2):119-122.

10. Ogbonna OA, Agwu AE (2013) Access and use of information communication technologies by rural farmers in Enugu north senatorial zone, Enugu state. Scholarly Journal of Agricultural Science 3(7): 264-270.

11. Gelb E, Offer A (2005) ICT Adoption in Agriculture: Perspectives of Technological Innovation.

12. GOI (2001) Report of Prime Minister's Task Force on India as Knowledge Superpower. Planning Commission, Government of India, New Delhi, India.

13. Munyua H (2007) ICTs and small-scale agriculture in Africa: a scoping study. Final Report to International Development Research Centre (IDRC).

\begin{tabular}{|l|}
\hline \multicolumn{1}{|c|}{ Your next submission with Juniper Publishers } \\
will reach you the below assets \\
- Quality Editorial service \\
- Swift Peer Review \\
- Reprints availability \\
- E-prints Service \\
- Manuscript Podcast for convenient understanding \\
- Global attainment for your research \\
- Manuscript accessibility in different formats \\
( Pdf, E-pub, Full Text, Audio) \\
- Unceasing customer service \\
Track the below URL for one-step submission \\
https://juniperpublishers.com/online-submission.php \\
\hline
\end{tabular}

